\title{
Ny høyesterettsdom om nakkeskade
}

\author{
16. desember 2010 avsa Høyesterett dom i en sak om krav om erstatning som følge av nakkeslengskade \\ etter en bilkollisjon. Domstolen stadfester de fire vilkår som må være oppfylt for at det skal foreligge \\ årsakssammenheng. Dommen viser at det er behov for en balansert fremstilling av hva som er allment \\ akseptert medisinsk viten til enhver tid og viktigheten av at domstolene foretar en fordomsfri vurdering \\ av bevisene i den enkelte sak.
}

\author{
Stein Chr. Hexeberg \\ sch@vogtwiig.no \\ Advokatfirma Vogt \& Wiig AS \\ Postboks 1503 Vika \\ 0117 Oslo
}

Høyesterett avsa 16.12. 2010 en dom i en sak der det ble krevd erstatning som følge av nakkeslengskade etter en kollisjon (1). Saken dreide seg om person $\mathrm{A}$, som våren 2002 var innblandet i og skadet $i$ en kjedekollisjon. Etter hvert ble smertene sterkere, og A fikk plager fra andre deler av kroppen. Etter halvannet år i arbeid ble A sykmeldt i desember 2003 og forble etter dette $100 \%$ arbeidsufør.

I dommen gikk Høyesterett gjennom medisinsk forskning om årsaker til smerteproblemer etter nakkesleng. Retten uttalte at det gjennom forskning ikke er påvist noen fysisk årsakssammenheng mellom nakkeslengtraume etter bilkollisjon uten objektive funn og senere utvikling av kroniske smerteplager, og at det må stilles strenge krav til dokumentasjon og årsakssammenheng i det enkelte tilfellet.

Høyesterett stadfestet tidligere praksis om at man ved vurdering av konkret årsakssammenheng må vurdere de fire vilkår som er oppstilt i rettspraksis for å anse at det foreligger en slik sammenheng (2). De fire vilkår som oppstilles i rettspraksis og som må være oppfylt for at det skal foreligge årsakssammenheng er:

- at ulykken må ha hatt såkalt skadeevne

- at det må foreligge akuttsymptomer

- at det må foreligge brosymptomer

- at den aktuelle personskadens utvikling må være forenlig med alminnelig medisinsk viten om denne type skader

I den aktuelle saken hadde den skadelidte et uvanlig sykdomsforløp: Smertene ble verre og omfattet etter hvert andre deler av kroppen enn nakken (1). De sakkyndige og Høyesterett la til grunn at det var en årsakssammenheng mellom ulykken og plagene begrenset til nakken, dvs. lette smerter og lett nedsatt bevegelighet. Disse plagene kunne ikke forklare utviklingen av et senere mer omfattende smertesyndrom og arbeidsuførhet. Erstatning ble derfor ikke tilkjent.

\section{Rettslige og bevismessige prinsipper}

Ved vurdering av årsaksforhold fastholdt Høyesterett prinsippet i den såkalte Liedommen fra 1998 - ved vurdering av årsaksforhold må man legge til grunn allment akseptert medisinsk viten og årsakssammenheng må vurderes konkret i den enkelte sak (2). Saken den gang gjaldt påkjørsel bakfra. Uhellet ble ikke ansett som årsak til tap i erverv. I den nye saken fra 2010 videreførte altså Høyesterett prinsippet at ved vurdering av bevis er det strenge krav til dokumentasjon, og at man skal legge særlig vekt på tidsnær dokumentasjon, for eksempel nedtegnelser $\mathrm{i}$ legejournaler. Høyesterett foretok en konkret årsaksvurdering ved gjennomgang av de fire vilkår som omfattende rettspraksis har lagt til grunn etter Lie-dommen. Det var således ingen kursendring $i$ de rettslige og bevismessige prinsipper som tidligere har vært rettspraksis i denne type saker.

\section{Medisinsk kunnskap}

Høyesterett uttalte i dommen at årsaksvurderingen kan være vanskelig i saker om nakkesleng (1). Vurderingen må skje ut fra allment akseptert medisinsk viten. Høyesterett viste særlig til redegjørelsen fra en rettsoppnevnt sakkyndig professor.

Den forskning som retten her ble forelagt, synes etter mitt skjønn å være ensidig. Fremstillingen i dommen er ikke balansert, ettersom studier og rapporter med andre konklusjoner ikke ble omtalt.

Som eksempel viste den sakkyndige til to studier fra Litauen der man undersøkte 400 personer som var blitt påkjørt bakfra med anslått gjennomsnittshastighet 30-40 $\mathrm{km} / \mathrm{t}(3,4)$. Nakkesleng var ikke kjent for helsevesenet i Litauen da undersøkelsen ble gjort, og det var ingen mulighet for erstatning. Konklusjonen var at etter ett år eller mer hadde personene like mye hodepine/ nakkeplager og plager fra kjeveledd som en kontrollgruppe som ikke hadde vært utsatt for noen påkjørsel. Høyesterett uttalte at antallet pasienter i studien var lavt, men at studien likevel gir en indikasjon på at andre forhold enn de rent fysiske skader kan ha betydning for symptomutviklingen.

I en rapport fra Senter for medisinsk metodevurdering (SMM) om nakkeslengskade ble all tilgjengelig litteratur vedrørende diagnostikk og evaluering av slike skader gjennomgått (5). Bakgrunnen var at Sosial- og helsedepartementet hadde tatt kontakt med senteret for å få utredet status for diagnostikk og evaluering av pasienter utsatt for nakkesleng i Norge. Utredningsgruppen var bredt sammensatt, og rapporten ble levert 9.6. 2000. Ekspertgruppen gjennomførte en systematisk innhenting og gjennomgang av tilgjengelig vitenskapelig dokumentasjon. Basert på en gjennomgang av 970 referanser oppfylte 73 artikler ekspertgruppens definerte krav og utgjorde den vitenskapelige dokumentasjonen i utredningen.

Litteraturgjennomgangen viste at svært få studier var kvalitativt gode nok til å danne en vitenskapelig basis for retningslinjer for undersøkelse og diagnostikk av personer som har vært utsatt for nakkesleng. Om den omtalte studien fra Litauen om forekomst av kroniske plager etter nakkesleng het det:

«Hvis vi på samme måte legger til grunn at ca. 14 prosent av den norske befolkning har kroniske nakkeplager uansett årsak, som påvist av Bovim et al. (18), og to prosent høyere forekomst av kroniske nakkeplager hos dem som er påkjørt bakfra, tilsier dette ( $\mathrm{p}=0,05$, ensidig test, statistisk teststyrke på 80 prosent) at man måtte hatt over 4000 personer i hver gruppe for med 80 prosent sannsynlighet å kunne avdekke en statistisk signifikant forskjell i forekomst av kroniske nakkeplager hos påkjørte og ikke-påkjørte.

Schrader og medarbeideres (84) funn fra Litauen er således basert på for små pasientmaterialer til at de er konklusive i forhold til hypotesen om hvorvidt påkjørsel bakfra fører til en økt forekomst av kroniske nakkeplager. I slike situasjoner med små utvalg kan man også oppleve at det vi forventer skal være positiv gruppeforskjell blir anslått til å være negativ, slik 
det var tilfellet i Obelieniene et al. (64). Studiene er derfor ikke konklusive.»

Etter mitt skjønn ville det vært naturlig at kritikken av studiene fra Litauen $(3,4)$ hadde fremkommet $\mathrm{i}$ den sakkyndiges gjennomgang av medisinsk forskning. SMMrapporten er ikke kommentert i dommen i det hele tatt (1).

\section{Sakkyndiges betydning}

Høyesterett uttalte i Lie-dommen at rettens behov for sakkyndighet må bli dekket på en betryggende måte (2). Hensynet til forsvarlighet og grundighet tilsier ofte at det oppnevnes to sakkyndige.

Medisinsk har man ufullstendige forklaringer på at enkelte utvikler kroniske plager etter nakkeslengtraume. Det er ulike leire blant medisinsk sakkyndige ved vurdering av årsaksforhold i denne type saker, herunder vurderingen av hva som er «allment akseptert medisinsk viten». Dette må domstolen være seg bevisst ved vurdering av sakkyndiges fremstillinger av medisinsk kunnskap. Fortrinnsvis bør domstolen legge mer vekt på bredt sammensatte ekspertgruppers vurdering av kunnskap om medisinsk forskning enn på vurderinger fra enkeltstående sakkyndige.

Når det gjelder den konkrete bevisvurderingen i den enkelte sak, har dommere vel så gode forutsetninger som medisinere til å vurdere konkrete bevis. Dommere er vel kjent med kravet til sannsynlighetsovervekt ved bevisvurderingen av årsaksforhold i erstatningssaker. Medisinere er ofte i sine vurderinger preget av krav til vitenskapelig bevis, som er langt strengere enn erstatningsrettslige beviskrav. I den enkelte sak må bevisene bli vurdert samlet, og det er tilstrekkelig med sannsynlighetsovervekt (dvs. mer enn $50 \%$ sannsynlighet) for å legge årsakssammenheng til grunn i det enkelte tilfellet.

\section{Fordomsfri vurdering}

Det er en kjensgjerning at en del av dem som utsettes for nakkesleng ved bilkollisjon, utvikler kroniske plager. Hensynet til rettssikkerheten tilsier at disse blir tilkjent riktig erstatning og ikke faller utenom grunnet at det i realiteten stilles strengere krav til bevis enn det som det er juridisk grunnlag for.

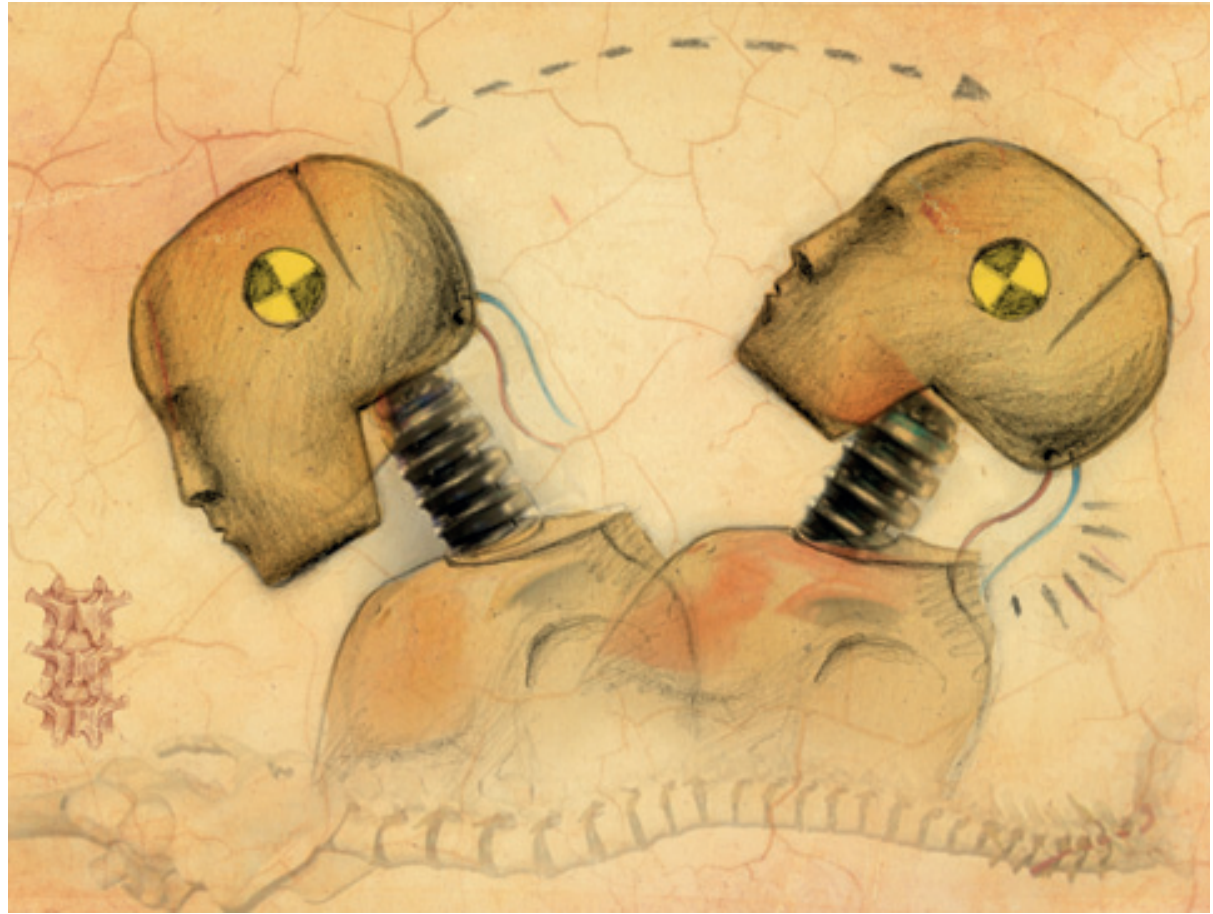

Illustrasjon Stein Løken

I den omtalte SMM-rapporten konkluderte ekspertgruppen med at ca. 3-5\% av alle som har vært utsatt for nakkesleng, utvikler symptomer (5). Vanligst er smerter i nakken og hodepine, kun et lite mindretall utvikler kroniske plager. Ekspertgruppen fremhevet at vi fortsatt står med ufullstendige forklaringer på denne tilstanden. Det viser behovet for at medisinsk sakkyndige og ikke minst domstolene foretar en fordomsfri vurdering av bevisene i den enkelte sak. Den nye høyesterettsdommen viser at det er behov for en balansert fremstilling av hva som er allment akseptert medisinsk viten til enhver tid.

\section{Stein Chr. Hexeberg (f. 1953)}

er advokat med møterett for Høyesterett og Master of Law fra University of Pennsylvania Law School. Han er partner i advokatfirmaet Vogt \& Wiig. Hexeberg arbeider med personskadeerstatning, forsikring og prosedyre. Ingen oppgitte interessekonflikter.
Litteratur

1. Norsk Retstidende 2010. Oslo: Den Norske Advokatforening, 2010: 1547.

2. Norsk Retstidende 1998. Oslo: Den Norske Advokatforening, 1998: 1565

3. Schrader H, Obelieniene D, Bovim G et al. Natural evolution of late whiplash syndrome outside the medicolegal context. Lancet 1996; 347: 1207-11.

4. Obelieniene D, Schrader H, Bovim G et al. Pain after whiplash: a prospective controlled inception cohort study. J Neurol Neurosurg Psychiatry 1999 66: $279-83$

5. Nakkeslengskade. Diagnostikk og evaluering SMM-rapport nr. 5/2000. Oslo: Senter for medisinsk metodevurdering, 2000. www.kunnskapssenteret.no/Publikasjoner/ attachment $/ 11054$ ? =true\&_ts $=12 \mathrm{cc5f03e} 26$ (16.5.2011).

Mottatt 20.1. 2011, første revisjon innsendt 5.5. 2011, godkjent 30.6. 2011. Medisinsk redaktør Petter Gjersvik. 